\title{
Housing in Port Harcourt, Nigeria: The Modified Building Approval Process
}

\author{
A. Ayotamuno \\ $\mathrm{PhD}$ student in Environmental Management \\ Institute of Geosciences and Space Technology (IGST) at Rivers State \\ University of Science and Technology (RSUST), Port Harcourt, Nigeria \\ E-mail: augustaayotamuno@yahoo.com
}

O. B. Owei

Department of Urban and Regional Planning, Faculty of Environmental Sciences, Rivers State University of Science and Technology (RSUST), PMB 5080, Port Harcourt, Nigeria;

E-mail: obo_owei@yahoo.com

Received: October 1, 2014 Accepted: October 21, 2014

doi:10.5296/emsd.v4i1.6824 URL: http://dx.doi.org/10.5296/emsd.v4i1.6824

\begin{abstract}
Housing is a process which makes the act of dwelling possible. In effect, the term, housing includes the house itself and the total surrounding environment with its ancillary facilities and services. One of the processes in building a house is the Building Approval phase before a house is started. This particular phase is marked by many challenges in Nigeria and particularly in Port Harcourt in the productivity of housing. The Rivers State Government in 2009 introduced the Rivers State Geographic Information System (RIVGIS) to handle land registration issues. Also in 2012, the "One -Stop -Shop" for building plan approval was introduced. The results have been rewarding; the various processes are more transparent, the period of waiting to get building approval and Certificate of Occupancy $(\mathrm{C}$ of $\mathrm{O})$ has been reduced, the number of structures built without permits and collapse of buildings are reduced, the practice of using quacks in the building profession is under check. Generally this has resulted in improved safety of life and property. However, challenges remain that require specific regulations and enforcement of such.
\end{abstract}

Keywords: Affordability, Modified Building Approval, Enlightenment, Housing, Land, 
Secure Tenure

\section{Introduction}

It is universally accepted that housing is the most important for the physical survival of man; the others being food and water (Aluko, 2004). Adequate shelter contributes to the attainment of physical and mental health of a nation and stimulates the social stability, work efficiency and development of the individual. Shelter is also a good investment and house owners often use their property as security. Shelter, both in units or multiple forms, is a significant component of the physical form and structure of a community, while the human and family contents of the house is part of the very spirit of life and prosperity of the society (Adeniyi, 1974).

Every nation has an obligation to provide its citizens with housing in line with the international declarations of human rights. Therefore the Nigerian Government through the National Housing Policy (NHP) of 1992 was formulated "to ensure that all Nigerians own or have access to decent, safe and sanitary housing in healthy environment with infrastructural services at affordable cost, with secure tenure" (NHP, 1992). This positions the housing sector as one of the prime drivers of the socio-economic development, including job creation and employment, as well as accelerated national transformation.

The building of a house involves several stages such as acquiring land, registration of the land (certificate of occupancy), architectural and engineering design of the house and obtaining Building Permit. This research is more interested in the building approval process and how this is affecting housing in Port Harcourt, Nigeria.

\section{Aims and Objectives}

The aim of the research is to:

(i) Find out the processes involved in building approval in Port Harcourt,

(ii) Identify the challenges that are hindering the modified process of approval, and

(iii) Proffer improved and efficient ways of ensuring the approval process is not arduous and more houses can be built in Port Harcourt.

\section{Research Problem}

Many developers and private individuals in Nigeria who want to be homeowners are having a lot of challenges to have affordable housing. They are constrained by a number of factors which include: high cost of building materials, stringent loan conditions from banks, and unfavourable government policies, high cost of land, difficulties associated with getting Certificate of Occupancy, building permit and access to credit. All these have led to the acute shortage of affordable houses in Port Harcourt. In Port Harcourt, where private rental housing is unaffordable to many tenants, security of tenure is threatened as they can often be legally evicted for non-payment of rent. Therefore the processes involved in getting Building Approval has been a major hindrance to housing productivity and that needs to be addressed.

\section{Study Area}

Port Harcourt was created by the British colonial administration between 1912 and 1914 to aid, 
through its coastal port, in the evacuation of agricultural produce, coal and for handling of trade from the hinterland. Initially the study area, which was named after the then British Secretary of State for Colonies, Lewis Harcourt, was just 30,000 acres, but with the discovery of oil in 1955 in Olobiri, Port Harcourt expanded quickly beyond its original boundaries(presently about $470 \mathrm{~km}^{2}$ ). Port Harcourt is located within latitudes $6^{0} 58^{\prime} \mathrm{N}$ to $7^{0} 6^{\prime} \mathrm{N}$ and Longitude $4^{0}$ $40^{\prime}$ to $4^{0} 55^{\prime} \mathrm{E}$. The climate falls within the sub equatorial climate belt. Temperature and humidity are high throughout the year. The area is marked by two distinct seasons - the wet and the dry seasons - with 70 percent of the annual rains falling between April and August, while 22 percent is spread in the three months of September to November. The driest months are from December to March. It falls almost entirely within the lowland rain forest ecological zone and is flanked in the east, west and southern limits by mangrove swamp forest (Ayotamuno and Gobo, 2004).

The growth of Port Harcourt and its region has been phenomenal since its inception. Growth has been experienced in terms of population and physical space. Two years after its founding the population was 5,000. Census figures for the city through its history are 7,185 in 1921; 15,201in 1931 and 71,634 in 1953 .The 1963 census gave the city's population as 179,563 and in 1973 it was 213,443 (Ogionwo, 1979). The 1991 census fixed the population of Port Harcourt and Obio/Akpor Local Government Areas at 645,883. The projection for 1996 by the National Population Commission is 832,471 for the two local governments and the interim figures for the 2006 national census is over one million. Spatially too, Port Harcourt city has grown to cover much of the Upper Bonny River Basin. Originally the city covered a $25 \mathrm{~km}^{2}$ area between the UTC junction and the New Layout Market. In the land use and vegetation map of Nigeria (1975/76) the built-up area of Port Harcourt covered $17.4 \mathrm{~km}^{2}$. Twenty years later, a similar map showed the extent of the city as $89.4 \mathrm{~km}^{2}$. This is a five-fold increase. By the 1976 Local Government Reform, the Port Harcourt Local Government Area Council stretched from Choba and Rukpokwu in the north, Iriebe in the east and the main western channel of the Bonny River in the west. This is an area of over $239.6 \mathrm{~km}^{2}$. Port Harcourt is still growing very fast and therefore the need, recently, for the establishment of the Greater Port Harcourt City (GPHC) by the Rivers State Government.

Port Harcourt, capital of the Rivers State, is the fastest growing city in the Niger Delta. Part of the need to control this rapid expansion is the creation of the Greater Port Harcourt City Development Authority (GPHCDA). The GPHCDA was established by "The Greater Port Harcourt City Development Authority Law" No. 2 of 2009, with a mandate to facilitate the implementation of the Greater Port Harcourt Master Plan and develop the 'New City'. The Greater Port Harcourt City Master Plan is a holistic plan for the development of the Greater Port Harcourt City which spans eight (8) Local Government Areas namely; Port Harcourt City, parts of Oyigbo, Okrika, Ogu/Bolo, Obio/Akpor, Ikwerre, Etche, Eleme local government areas respectively, with a population of approximately 2 million people. The Master Plan is for a period of 50 years, it will be reviewed periodically to ensure that it continues to meet with changing realities of an emerging city. The key anchors of the New City are the Port Harcourt International Airport, the Old City and the Onne sea port. The Greater Port Harcourt Area which comprises the whole of Port Harcourt and the aforementioned local government areas, a 


\section{Macrothink}

total landmass of $19,000 \mathrm{~km}^{2}$ ( Ede, Owei and Akarolo, 2008). Below is a map of the study area.

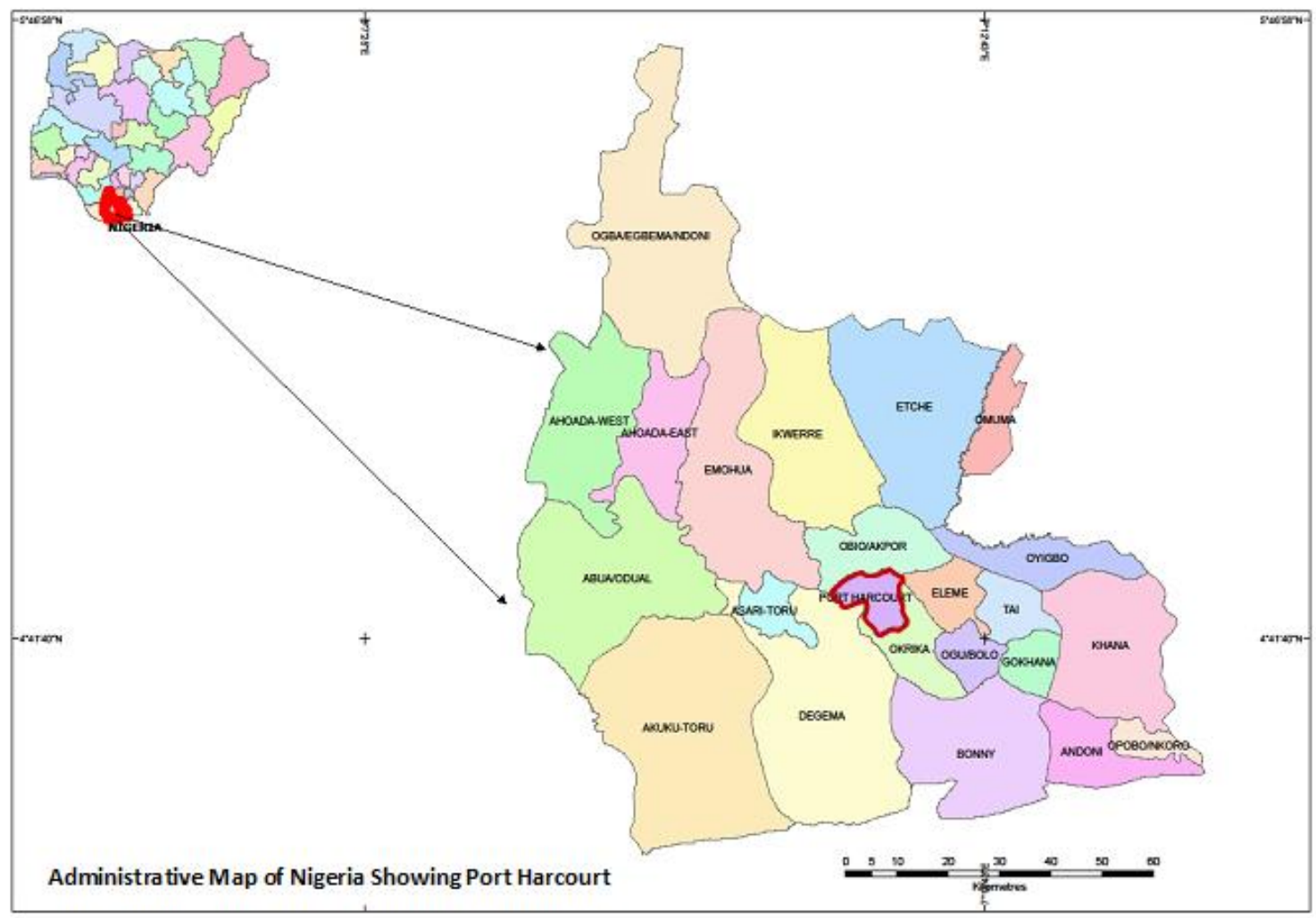

Figure 1. Map of Nigeria Showing Port Harcourt HHHHarcourt

\section{Methodology}

The methodology approach adopted for the study consisted of review of previous housing deliveries and the building approval processes in those countries and states. Literature search, collection of data from some of government agencies and in-depth interviews with key informants in those agencies including: the National Population Commission, Rivers State Ministry of Urban Development and Physical Planning, Rivers State Geographic Information System (RIVGIS). The directors of the above government agency were those engaged in discussion and their responses recorded. They stated the challenges and the progress they have made in their various agencies with regard to building plan approval. Also they willingly gave the necessary data which has been analyzed and used for this research.

\section{Housing in Port Harcourt}

The 2006, National Population Census statistics showing the distribution of the households by type, a total of 126,010 households were recorded in Port Harcourt. The data shows that houses on a separate stand or yard were 49,115 , traditional/hut structure made of traditional materials were 371 , flat in block of flats 27,676 , semi detached house 8074 , room/let in house 36,584, informal/improvised dwelling 2078 and others 2112. Also distribution by tenure in Port Harcourt there was a total of 126,010 households, owner occupier were 25,882, owned but not yet paid 1107, rented 90,412, occupied rent free 7229 , squatting 957 and others are 
423. The 2006 Census data shows that most of the houses are privately owned. Port Harcourt's housing is mostly privately owned or rented and many families in Port-Harcourt are inadequately housed because of low incomes or other circumstances such as: high cost of land, lack of security of tenure, high cost of rents, poor accessibility, and inadequate housing services. All of these prevent many families from competing successfully in the private housing market. For these families, the city or government has the obligation of improving their living conditions by providing adequate low and moderate income housing or by administering state public programmes which create opportunities for improved housing (Ogionwo, 1979). Almost all public sector efforts to provide housing for the masses of low income people in the city have either been hijacked by the rich or so poorly implemented as to have any significant impact (Oruwari, 1991).

According to a social survey of Port Harcourt by Ogionwo, (1979) undertaken in connection with the preparation of the Greater Port Harcourt Master Plan (1975), found that only $10 \%$ of Port Harcourt households owned the housing units in which they lived, while almost $90 \%$ were renters. It was also found that Port Harcourt possessed a mixture of residential types. In most neighbourhoods there were one, two or three-family bungalows alongside two and three-storey buildings and traditional compound houses were found to be of the U-shaped type, incorporating a central courtyard, with the number of single rooms ranging from 6-24. Of the surveyed housing stock, $34.2 \%$ were considered standard (i.e. those with no defects, or only slight defects which would normally be corrected during the course of regular maintenance); $37.8 \%$, deteriorating (i.e. those that need more repair than would be provided in the course of regular maintenance); and $20.0 \%$, deficient (i.e. those which do not provide safe and adequate shelter). A remarkable feature of the housing situation in Port Harcourt is the slow pace of replacement/refurbishment of the obsolescent stock. Undeniably, some gentrification or cellular renewal is occurring in the Main Town and in Diobu; but certainly not at a pace to make any significant impression on the townscape or provide sufficient rental units of various kinds in the face of massive demand. The bulk of new housing construction is occurring on the city's periphery by (a) speculative developers providing largely rental flats and (b) the rich, building for owner occupation.

From all indications, it will be deduced that the various housing projects being undertaken by some of these institutions, whether through partnership or otherwise were targeted at the higher income earners, who mostly have homes and are capable of acquiring more. A middle or low income earner might not see reasons for him/her to pay as much as 40 million naira (about 235, 300 USA dollars) or 35 million naira (about 205,900 at USA dollars), at present day exchange rates, for a four or three bedroom flat, whether detached or semi-detached. Solving housing problems in Port Harcourt will not be feasible if the middle and low income earners are not taken care of in the scheme of things. This is because they constitute the majority of residents that make demand on housing. The challenges of sourcing for funds or mortgage, land acquisition and other bottle-necks in terms of getting the necessary papers that confer the right of ownership or otherwise known as the Certificate of Occupancy ( $\mathrm{C}$ of $\mathrm{O}$ ) have posed many problems to middle and low-income earners in the quest of owning a house.

\section{Title to Land (Certificate of Occupancy)}




\section{Registration of Land}

The Nigerian legal system is based on the English common law system as it concerns mortgages and property transactions. Land ownership is backed by the Land Use Act CAP L5 Vol. LFN 2004 initially promulgated under the military in 1978. This Act vests ownership of all land in the Governor of each state, who has the rights and privileges to allocate land through a leasehold system. The lease is generally for 99 years less one day. In reality, this right of occupancy is legalized with a Certificate of Occupancy issued to the beneficiary. This often delays and adds significant costs to the registration process (Agbola, 1987). In all areas of the country, $65 \%$ to $70 \%$ of land is still held under customary title. Families or communities that want to transform such land for development must subject themselves to the dictates of the Act. Land allocated under the leasehold structure must be developed within three years or the Governor can take back the land. However, notices are often given instead to the owners of the land when they have flouted this clause. Computerized land registries are being introduced, starting with Lagos and Abuja. In Lagos, assistance from the British Council and the Land Registry in England and Wales has helped in championing this exercise. In Abuja, a computerized title registration system and cadastral mapping using Geographical Information System (GIS) has begun and titles can be printed out on secure, numbered paper at the Abuja GIS office on request. This has improved the search for titles, which previously took several weeks to complete.

Much work is, however, still needed. In 2007, the World Bank ranked Nigeria 173 (out of 178) in the country ranking of registering property (Doing Business, 2007), with 14 procedures, 82 days duration, and costs of $22.2 \%$ of property value. While the figures show an improvement on the 2006 figures of 16 procedures (Simon, 2009), 274 days and 27.1\%, Nigeria's performance in registering property is one of the major contributors to its 108th place in the World Bank's. Thus, a lot still needs to be done in Nigeria when compared to Norway and Singapore where it takes a single day. A recent report stated that 16 procedures are required to register property in Nigeria (Akeju, 2007). From literature different researchers have different time duration but they all point to one fact. That the time and procedure it takes for $\mathrm{C}$ of $\mathrm{O}$ is extremely long and there is room for improvement. We should however note that part of the reduction in time is likely as a result of improvements in property registration which has been implemented in Abuja and Lagos. In fact the Doing Business indication of 82 days is based on a test case of property registration in Lagos. Other state governments are considering replicating the improvements achieved in the Abuja Geographic Information System (AGIS) and Lagos State. On $26^{\text {th }}$ September 2013 the Deputy Governor of Rivers State, in a television address to the Nigerian Society of Estate Surveyors and Valuers, said that the state is working towards land registration process taking only 30 days.

The 2003 law for Physical Development provided for the establishment of a State Planning Board and Planning Authorities in all (23) local government areas of River State. It has never been implemented. The same lassez-faire attitude has also been taken in the implementation of the State Land Development and Land Registration Laws. Section 4 of the Land Development (Provision for Roads) Law initially dated 1933 gives conditions that are to be complied with before land is sold off in plots. This includes the making of planning schemes that indicate what 
parts of the land were to be reserved for roads. Local land owners are obviously not acting in recognition of this law. CAP 74 of the laws of Rivers State dates back to 1917 and provide for land registration under colonial rule. As it was then and even presently, this law is abused by government officials, communities and private buyers as the transfer of titles to land in Port Harcourt goes on mostly outside the formal governmental processes and channels. The greater proportions of developers do not possess the Certificate of Occupancy which is the statutory title to land. Port Harcourt has no clearly defined settlement development policy; neither does it have a clearly defined urban growth management policy (Owei \& Ikpoki, 2006). The implementation of the Land Use Act in facilitating access to land has been very selective, especially benefiting those in public office and their supporters. Public sector land delivery has proved to be an inefficient regulatory tool for urban land management. Thus, the inefficient urban planning system has promoted urban sprawl, with the bulk of development unplanned and unregulated (Obinna, Owei \& Mark, 2010).

\section{Rivers State Geographical Information System (RIVGIS)}

A lot of people who wish to build or own their own homes cannot do so because they do not have Certificate of Occupancy ( $\mathrm{C}$ of $\mathrm{O}$ ) or land title on their land, which is not easily issued. This is particularly bad in the South/South region of Nigeria and worse in Port Harcourt. The situation has come to the notice of the Rivers State Government, so it introduced in 2009 the Rivers State Geographic Information System (RIVGIS) to handle land issues. Over the years, the analogue land management system adopted in Rivers State has led to cumbersome and frustrating processes of land title documentation. RIVGIS is a computer - based land management tool expected to provide the much needed solutions to the problems of the outdated analogue system. The Project is being executed under the Public Private Partnership initiative of the government through the Ministry of Lands and Survey, Port Harcourt in partnership with an indigenous firm- Megatech Earth Digital Systems Limited (RIVGIS 2013).

RIVGIS had to do file indexing, land registration and by 2010 things kicked off. By 2011 the first set of digital Certificate of Occupancy $(\mathrm{C}$ of $\mathrm{O})$ were given out about 72 in number. As at the time of this research 2013, over 200 C of O's has been given out. Presently there is still a back log of applications not treated because some of them have wrong survey plans. In the process of treating the back log of applications, the survey plans cannot be used directly because of wrong coordinates used previously by private surveyors. About $90 \%$ of the previous survey plans done by analogue style have errors and need to be redone. It is only the survey general that can issue coordinates. Some applicants are not ready to follow the process and have abandoned it half way. Still others are complaining on the various fees to be paid that it is too expensive depending on the location of the land (RIVGIS, 2013). Below is the time line stipulated by Government to get the Certificate of Occupancy. However, it is important to note that this time line is often not met because of many other shortcomings of the process not least of which are bureaucratic bottlenecks, and undue politicization of the process.

Table 1. Time Line Registration of Certificate of Occupancy in Rivers State

\begin{tabular}{|l|l|l|l|}
\hline S/NO & TASK & DURATION & ACTION \\
\hline 1 & Sale of Application Forms & 1 Working Day & Director Land Use and Allocation \\
\hline
\end{tabular}




\begin{tabular}{|l|l|l|l|}
\hline 2 & $\begin{array}{l}\text { Submission of Application Forms/ } \\
\text { Opening of File }\end{array}$ & 2 Working Days & Director Land Use and Allocation \\
\hline 3 & Charting/ Description & 10 Working Days & Office of the Surveyor-General \\
\hline 4 & Pre-Publication Activity & 7 Working Days & Director Land Use and Allocation \\
\hline 5 & Publication & 30 Days & Director Land Use and Allocation \\
\hline 6 & Objection Hearing (if any) & Permanent Secretary \\
\hline 7 & Approval of Objection-Free Application & 9 Working Days & Honourable Commissioner \\
\hline 8 & $\begin{array}{l}\text { Scanning and Indexing of Approved } \\
\text { Application/Storage of File }\end{array}$ & 3 Working Days & Coordinator RIVGIS \\
\hline 9 & $\begin{array}{l}\text { Issuance of Demand Notice For Deed } \\
\text { Fees }\end{array}$ & 2 Working Days & Coordinator RIVGIS \\
\hline 10 & Confirmation of Payment & 2 Working Days & Director of Finance \& Accounts \\
\hline 11 & $\begin{array}{l}\text { Preparation of Certificate of Occupancy } \\
\text { including Biometrics and Hologram }\end{array}$ & 5 Working Days & Coordinator RIVGIS \\
\hline 12 & $\begin{array}{l}\text { Forwarding of Certificate to Honourable } \\
\text { Commissioner for Recommendation to } \\
\text { His Excellency }\end{array}$ & $3-5$ Working Days & Coordinator RIVGIS \\
\hline 14 & Signing of Certificate of Occupancy & 7 Working Days & His Excellency \\
\hline & Stamp Duty/ Registration/Delivery & 90 working Days & Director, Deeds Registration \\
\hline
\end{tabular}

Source: RIVGIS, 2011

\section{The Building Permit System in Port Harcourt}

The Planning Permission or Planning Consent is the permission required by the developer in order to be granted approval from the Rivers State Ministry of Urban Development and Physical Planning to carry out development on land.

The Land Use Management Scheme (LUMS) is the tool used to guide the making of such decisions and ensures development is in the right place and manner. It helps to maintain a balance between development, growth and environmental sustainability. All developers wishing to commence development of plots, temporary or permanent, within the state shall apply on prescribed application forms obtainable upon payment of the relevant fees from the Ministry. A Building Plan approval is necessary before construction can commence. This is to ensure that the building complies with building laws and codes and to prevent people from just constructing as they deem fit. Hence, the very first thing to do when you want to commence construction is to obtain a Development Permit from the State Government and the office in charge is the Rivers State Ministry of Urban Development and Physical Planning. There is a checklist provided for Buildings Plans. Below is a table showing the check list for Building permit.

Table 2. Check List for Building Plan Approval

\begin{tabular}{|l|l|}
\hline 1 & $\begin{array}{l}\text { Title Document (C of O, Assignment with Consent Certificate signed by Hon. Attorney - General and } \\
\text { Commissioner for Justice, Lease or Deed of Conveyance with evidence of application for C of O), etc. }\end{array}$ \\
\hline
\end{tabular}




\begin{tabular}{|c|c|}
\hline 2 & Income Tax Clearance Certificate for Individuals \\
\hline 3 & Certificate of Incorporation Company/Organization Tax for corporate bodies \\
\hline 4 & Soil Test Report prepared by qualified firms, Engineers, etc and address \\
\hline 5 & Copy of Workmen Compensation Insurance Certificate \\
\hline 6 & Letter of conformity from Client including Name, Residence/Office Address and Telephone Number. \\
\hline 7 & $\begin{array}{l}\text { Six (6) sets of drawings duly signed and sealed by the relevant professionals with CVs attached ie } \\
\text { Architect, Structural, Mechanical \& Electrical Engineers and calculation sheets for all structural } \\
\text { drawings }\end{array}$ \\
\hline 8 & $\begin{array}{l}\text { Name of the Site Engineer/Builder, his Qualification(s) Registration Number, Residential and Office } \\
\text { Address, his passport photograph, phone number and a letter of Undertaking accepting full } \\
\text { responsibility for the construction. }\end{array}$ \\
\hline 9 & $\begin{array}{l}\text { Survey Plan Charting Report from the office of the Surveyor General of Rivers State for new } \\
\text { development areas or land without Certificate of Occupancy or Registered Instrument. }\end{array}$ \\
\hline 10 & Structural Integrity Report for existing Building with Structural Drawings. \\
\hline 11 & Site Analysis Report \& Location Plan (SAR \& P) duly prepared by a Registered Town Planner. \\
\hline 12 & $\begin{array}{l}\text { Environmental Impact Assessment Report duly prepared by a Registered Town Planner in respect of } \\
\text { application for: } \\
\text { a) A Residential land in excess of } 2 \text { hectares and /or development in excess of } 4 \text { floors or } 8 \text { family units; } \\
\text { b) Factory building or expansion of factory buildings } \\
\text { c) Place of worship; } \\
\text { d) Major recreational development covering more than } 2,000 \text { square meters; } \\
\text { e) Institutional buildings; } \\
\text { f) Petrol filling/Service Station; } \\
\text { g) Any other type of commercial and industrial buildings not described in paragraph } 11(\mathrm{a}-\mathrm{f}) \text { above. }\end{array}$ \\
\hline
\end{tabular}

Source: Ministry of Urban Development \& Physical Planning, 2013

To obtain a Building Plan Approval, the following process is required.

1. Architectural design is submitted for inspection to confirm if design is in conformity with the approval standards and order for the area which the land is located.

2. If documents are found satisfactory, assessment will be given. The assessment is based on the volume of your building multiplied by the rate applicable to your land location.

Usually, a bank draft is made payable to the Rivers State Government, the relevant local planning authority of the land location and the Rivers State Ministry of Urban Development and Physical Planning. You might also need to pay some additional fees to Rivers State Government depending on your proposal.

3. Before submission of your application, the site will be inspected. This is the first of various inspections that your site will be subjected to. The reason is to know if the site in question is the same as the one being proposed for development and also, that you have not commenced construction before building plan approval.

The site will also be checked with the immediate environment to see if proposal is in conformity with the existing land use, and if the size of the plot is as presented in the survey 
plan and design proposal. If the inspection report is satisfactory, the application will then be registered, provided all documents have been submitted.

The above procedure was the case several years back in Port Harcourt and the delay in getting building approval was too long. There were also administrative delays when the applicant's file had to be sent back and forth from one government agency to the other to verify different aspects of the drawings. Those who applied for building approval could wait as much as 2 years. This was obviously affecting development in the city. Many developers simply ignored the process and went ahead to build. In the situation where monitoring is weak and existing development control measures are not applied, the city became largely unplanned. Some developers finished building and even moved into the house before the approval process went through. This resulted in a lot of uncertified structures being erected and some of the consequences were the regular collapse of buildings and loss of life and property in Port Harcourt.

The Rivers State government then introduced the 'One - Stop - Shop' in 2012. This policy meant that all the above processes of getting building plan approval are carried out in one office. All the professionals in the building industry who need to give approval for development of structures are members of the committee and are present on the scheduled days for approval. The state chapter chairmen or the representatives of the following professional bodies are usually in attendance; Architects, Engineers, Town Planners. They check the drawings if they are done by certified and registered professional members and if the drawings are of the required standards. For the developer to commence building, the Site Engineer or Project Manager will sign an undertaking to be responsible to build to specification and ensuring Best Practice on the site, with his recently taken passport photograph. A lot of measures have been put in place to ensure that quacks do not practice and that Best Practices are observed. This includes the use of professional seals. The office of the Commissioner for Urban Development and Physical Planning employed ad-hoc staff. These ad-hoc staffs are trained and help with inspection during the approval stage and through the construction stages of the building to ensure that people comply with the standards required on every site. With the above put in place building approvals in Port Harcourt are faster because the process is transparent and not cumbersome. Also the collapse of buildings has reduced so drastically and approval is faster. There have been records of applicants receiving building plan approval within one month if all the documents are complete. Table 3 below shows records of application of Building Approval.

Table 3. Registered and Approved Building Plans August 2012 to May 2014

\begin{tabular}{|c|c|c|c|c|c|}
\hline S/No & Date & Registered & Approved & Collected & Not yet Approved (incomplete documentation) \\
\hline 1 & Aug, 2012 & 97 & 10 & 10 & 87 \\
\hline 2 & Sep, 2012 & 68 & 14 & 14 & 54 \\
\hline 3 & Oct, 2012 & 69 & 35 & 22 & 34 \\
\hline 4 & Nov, 2012 & 79 & 51 & 32 & 28 \\
\hline 5 & Dec, 2012 & 73 & 63 & 60 & 10 \\
\hline 6 & Jan, 2013 & 85 & 76 & 71 & 9 \\
\hline 7 & Feb, 2013 & 151 & 132 & 125 & 19 \\
\hline
\end{tabular}




\begin{tabular}{|c|c|c|c|c|c|}
\hline 8 & Mar, 2013 & 135 & 115 & 111 & 20 \\
\hline 9 & Apr, 2013 & 94 & 79 & 65 & 15 \\
\hline 10 & May, 2013 & 110 & 88 & 82 & 12 \\
\hline 11 & Jun, 2013 & 86 & 70 & 68 & 16 \\
\hline 12 & Jul, 2013 & 109 & 99 & 94 & 10 \\
\hline 13 & Aug, 2013 & 86 & 62 & 61 & 24 \\
\hline 14 & Sep, 2013 & 49 & 45 & 45 & 5 \\
\hline 15 & Oct, 2013 & 122 & 115 & 105 & 7 \\
\hline 16 & Nov, 2013 & 99 & 83 & 80 & 16 \\
\hline 17 & Dec, 2013 & 66 & 51 & 51 & 15 \\
\hline 18 & Jan, 2014 & 120 & 99 & 90 & 17 \\
\hline 19 & Feb, 2014 & 126 & 109 & 97 & 3 \\
\hline 20 & Mar, 2014 & 128 & 125 & 118 & 10 \\
\hline 21 & Apr, 2014 & 84 & 74 & 70 & 37 \\
\hline 22 & May, 2014 & 94 & 57 & 56 & \\
\hline & Total & 2130 & 1643 & 1527 & \\
\hline
\end{tabular}

Source: Department of Building Plan Approval and Regulations, Ministry of Urban Development \& Physical Planning, 2014.

From table 3, there has been considerable success in the Building Approval process in Port Harcourt. The initial response was slow because people were not use to this method of doing things but over time they realized that the government was committed to getting things right. They gradually started responding and following due process. The total number of applications for Building Approval as recorded since the "One Stop Shop" commenced up until May 2014 is 2130. Total numbers of approved applications are 1643, while those who have collected are 1527. The statistic shows that even some of the applications that have been approved, have not been picked up. The reasons could vary from the individuals not knowing the exact time the whole process will last and not been informed that their Building Approvals are ready. Others may just be a blithe attitude to things.

Some of the documents required for Building Approval such as three years tax clearance are difficult to get or developers are reluctant to obtain such documentation as it involves income declaration. The Certificate of occupancy which is the title to land is also extremely difficult to obtain. These are some of the issues that make incomplete documentation. It is interesting to note that these two documents are issued by government. For some types of developments, soil tests are required which also involves money. Other sources of delay include the fact that the drawing plans have not met control guidelines in terms of setbacks from access roads, and between buildings, size of rooms, provision of building services and also plot coverage. The poor communication between the planning office and developer increases the delays. Obviously, these delays open up the process to abuse.

The Modified Building Approval process is designed to follow Best Practices. It is expected to reduce delays and open up the approval process so that the developer is properly informed at all stages. The results show increase in numbers of applications and reduction in the time it takes 
to process applications. This is a positive development. Furthermore there are improvements in the safety of structures in Port Harcourt

\section{Conclusion}

Building Approval Process in Port Harcourt is undergoing a lot of changes which are increasing transparency. These changes are making it easier and faster for developers and intending homeowners to get approvals before development starts. This has been made possible through the introduction of Rivers State Geographic Information System (RIVGIS). In addition is the positive impact of the 'One -Stop -Shop' policy of the Rivers State Ministry of Urban Development and Physical Planning. With the synergy of the professional bodies in the building industry joining forces at the "One Stop Shop", there has been a reduction in; the use of quacks, the number of illegal structures and collapsed buildings. It is expected that the net effect will be a better planned city.

\section{Recommendations}

1) The fees for the registration of land and building approval are still expensive and needs to be reviewed to enable developers pay.

2) The citizens need to be educated on the workings of the modified land registration and building approval processes. Also there is need for them to comply in getting their old survey plans redone to have the appropriate coordinates for charting.

3) More qualified full time staff, are required to be employed and trained for efficiency to keep pace with the expansion of the city. The use of ad-hoc staff is unacceptable as they do not possess the requisite training to perform development control functions.

4) The Ministry needs a functional website and better communication with applicants to give update on their approval and registration progress.

5) The provisions of the Rivers State Planning and Physical Development Law should be implemented to give legal backing to the development control functions of the ministry.

\section{References}

Agbola, Tunde (1987). The Housing Problems in Nigeria Cities. Town Planning Review, Vol. XLVII, No. 4. $339-347$

Adeniyi, E. O. (1974). The Provision of Housing: A Challenge to Urban Planning and Development in Africa, Ibadan NISER reprint series 96, 701-710.

Akeju, A. A. (2007). Being a Paper Presented at the 2nd Emerging Urban Africa International Conference on Housing Finance in Nigeria, Held at Shehu Yar'adua Center Abuja, October 17-19.

Aluko, E. O. (2000). The Effect of Relative Units of Housing on House Price in Metropolitan Lagos, Lagos. J. Environ. Stud., 2(1), 85-94. 


\section{Macrothink}

Ayotamuno, M. J., \& A. E. Gobo. (2004). Municipal solid waste management in Port Harcourt, Nigeria: obstacles and prospects. Journal of Management of Environmental Quality. 15(4), 389-398. http://dx.doi.org/10.1108/14777830410540135

Ede, P., O. B. Owei \& Akarolo, C. (2011, Wuhan). Does the Greater Port Harcourt 2008 meet aspirations for liveable city? Paper presented at the $47^{\text {th }}$ Congress of the International Society of City and Regional Planners. Liveable Cities: Urbanizing World, Meeting the Challenge. Wuhan. Retrievable from http://www.isocarp.net/Data/case_studies/1859.pdf

Federal Republic of Nigeria, National Housing Policy (NHP) (1992). Government of Rivers State of Nigeria (2008).

Greater Port Harcourt City Development Master Plan (2008). Arcus Gibbs. Vols 1-4.

Greater Port Harcourt City Development Authority (2009). http/www.GPHCDA/ (Accessed on: September 29, 2013).

Obinna, V. C., Owei, O. B., \& Mark, E.O. (2010). Informal settlements of Port Harcourt and potentials for planned city expansion. Environmental Research Journal, 4(3), 222-228. Medwell Journals. http://www.medwelljournals.com/fulltext/?doi=erj.2010.222.228

Ogionwo, W. (1979). A Social Survey of Port Harcourt. Ibadan. Heinemann Educational Books Nig. Ltd.

Oruwari, Yomi (1991). Housing Finance for the Urban Poor in Nigeria: the role of the Public Sector' in: Saglamer, G. \& Ozuekren, S. (eds.) Housing for the Urban Poor. ENHR International Symposium, Instanbul; Istanbul Technical University.

Owei, O. B., \& Ikpoki, M. (2006). The growth of middle and high income informal settlements in Port Harcourt". In Z. M. Enlil and P. Vaggione (Eds.), Cities between integration and disintegration: opportunities and challenges (pp.193 - 204). The Netherlands: International Society of City and Regional Planners.

Rivers State Geographical Information System (RIVGIS) (2013).

Simon, W. (2009). World Bank, Making Finance Work for Nigeria http://dx.doi.org/10.1108/14777830410540135

\section{Copyright Disclaimer}

Copyright for this article is retained by the authors, with first publication rights granted to the journal.

This is an open-access article distributed under the terms and conditions of the Creative Commons Attribution license (http://creativecommons.org/licenses/by/3.0/). 